\title{
Identity in Changing Context: Factors of losing Identity in new developed part of the city of Famagusta, North Cyprus
}

\author{
*Dr. Hourakhsh Ahmad Nia 1, MA. Yousif Hussien Suleiman ${ }^{2}$
}

1 \& 2 Department of Architecture, Nawroz University, Duhok, Kurdistan Region, Iraq

\section{ARTICLEINFO:}

Article history:

Received 20 February 2017

Accepted 7 May 2017

Available online 7 May 2017

Keywords:

Identity;

Changing Context;

Globalization;

Urban sprawl.

This work is licensed under a

Creative Commons Attribution

NonCommercial - NoDerivs 4.0.

"CC-BY-NC-ND"

E mail: hourakhsh_ahmadnia@yahoo.com ,E mail: Yousif.Sulaiman@nawroz.edu.krd

\begin{abstract}
A B S T R A C T
Historical cities due to its magnificent building in its context have tremendous influence on formation of city identity, which is created through the interaction of natural, social and built elements. Unfortunately modernization after the industrial revolution couldn't adapt itself to vernacular area, owe to the fact that cities began to lose their identity and sense of belonging to the environment. New technology of construction lets the cities to expand itself outside, but in this transformation, some factors which have an influence on the identity of the city have been forgotten. In this research it is aimed to analysis Physical and social factors which are causing the loss of identity in the city of Famagusta (Gazimagusa). Both qualitative and qualitative methods have been used in this research and the adopted techniques are personal observation, sketches, and comparing new development part of the city with traditional part. The research will try to answer the question of why urban sprawl could not maintain the identity of the city of Gazimagusa?). This research revealed that Globalization by neglecting historical housing principles is the main factor which threatening identity of the city. JOURNAL OF CONTEMPORARY URBAN AFFAIRS (2017) 1(2), 11-20. https://doi.org/10.25034/ijcua.2017.3644
\end{abstract}

\section{Introduction}

"City identity is a strong concept or conditions that differ cities from other locations. The city identity creates images in people's mind even that haven't seen it before. It is an essential characteristic for creating better environments" (Fasli, 2010). Unfortunately in the new development part of cities there is not any potential to attract people to place. These places converted to lost spaces due to lack of mixed use functionality. The new places don't have meaning to its users. In this area the role of Globalization in the new development part of the city should be considered, it seems that the Globalization by changing in social and cultural structure changes meaning of identity of cities. Understanding which factors have more effect

\footnotetext{
*Corresponding Author:

Department of Architecture, Nawroz University, Duhok,

Kurdistan Region, Iraq

E-mail address: hourakhsh_ahmadnia@yahoo.com
} 
on the changing identity of the city of Famagusta in new development part of the city related to its traditional housing environment, will be the main issue in this research. In this study, the city identity related to its Physical, socioeconomic, socio-cultural structures and historical factors will be explained.

\subsection{Literature review}

\subsubsection{Globalization and its effect of urban context}

By considering the meaning of Globalization "the act of globalizing, or extending to other or all parts of the world and Worldwide integration or development" (Dictionary, 2012), it's obvious that the process of globalization is against the cultural and regional identity of a city. It means that "globalization has resulted in the loss of some individual cultural identities" (Kutsal, 2012). The context of urban area in these recent decades has been radically changed. Similar patterns of housing construction rapidly expanded itself all around the world. Unfortunately the process of Globalization and similar construction ruined city's historical icons which had influence on the identity of the cities. Socio cultural, social physical changes in the context of the city changes fashion and lifestyle of the peoples. It's obvious that during the past decades the world has been changed because of technological innovation and global restructuring. Since the first decades of the twenty century. Nowadays the processes of Globalization affect all countries, thus this led to effects on social and cultural lives. "The globalization process leads the cities to be in a uniformed type; eventually, influences the living spaces, architecture and urban identity. The economic changes take place as a result of the development process of the cities, where urban image differs and changes" (Kutsal, 2012). "Globalization is now an unstoppable historical process led by technological change and involving the dissemination of science and new technologies" (Eldemery, 2009).

\subsubsection{The effect of Globalization on Urban sprawl} Because of the essence of technology, and rapidly increasing population of the city and due to dynamic of urban growth the city has to be expanded itself to outside. Mass housing construction without attention to its surrounding and Environmental and Social Identity (e.g., Socio-Cultural, Socio-Political, Socio-Economic) for this reason scholars called this phenomena as urban sprawl. In the literature of urban planning or urban economics, "there is a big debate on even the definition of urban sprawl itself, let alone its causes and impacts" (Gordon and Richardson, 1997; Ewing, 1997; Fischel, 1999; Brueckner, 2001). Generally, the definition of urban sprawl appears that, "First, it has to be an inefficient or an excessive urban expansion, which certainly involves some benchmark of 'normal' or efficient urban structure; second, if determined inefficient or excessive, the spatial pattern may be in leapfrog development, low density, or some other forms" (Deng, 2004). This discussion revealed that global technology of construction lets the city to expand itself outside, but in this transformation, some factors which have an influence on the identity of the city have been forgotten. For this reason it's obvious to say that Globalization by neglecting icons of identity of a city in transformation period create images of unsustainable city.

\section{Methodology}

Famagusta (Gazimagusta) city in North Cyrus has a problem of urban sprawl with two types of free standing villas and cubic form of four or five story buildings which don't have any relationship with its surroundings. In this era, understanding why urban sprawl could not maintain the identity of the city will be the main issue in this research.

\subsection{Case study: The City of Gazimagusa}

Gazimagusa, the second largest city of Northern Cyprus with a population of 35.000 (URL4. 2013), is situated on the eastern coast of the island of Cyprus in the Eastern Mediterranean Sea. "The city reflects a long and unique history in the form of a rich cultural, urban and architectural 
heritage in its older core, the Walled City, a fortified medieval city dating back to the 15th century" (Oktay, 2001). Medieval walled city of Famagusta due to its port and magnificent historical building with human scale narrow streets (organic pattern) and its traditional context have a tremendous identity which works in global scale. As Önal et al. (1999), in her paper of "The urban problems of Gazimagusa (Famagusta) and proposals for the future" discuses about urban growth of Gazimagusa by reflecting the fact that after the industrial revolution from 1960 rapid urban growth started to expand itself in the suburb but in this rapid urban growth it seems that something have been forgotten from vernacular housing construction point of view.

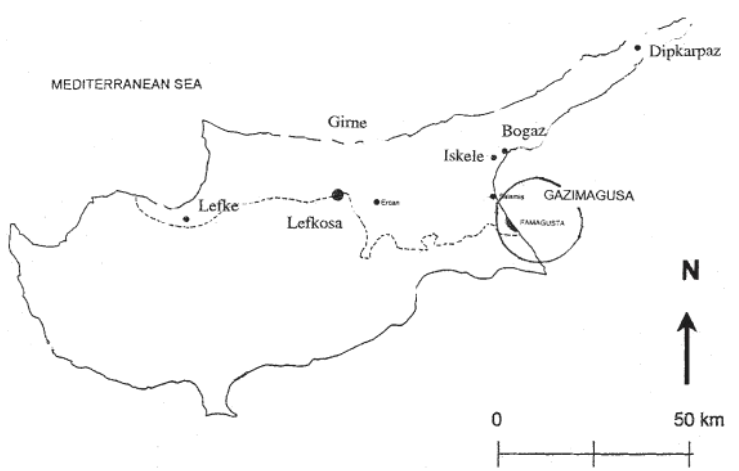

Figure 1. Location of Gazimagusa in North Cyprus (Onal et al., 1999).

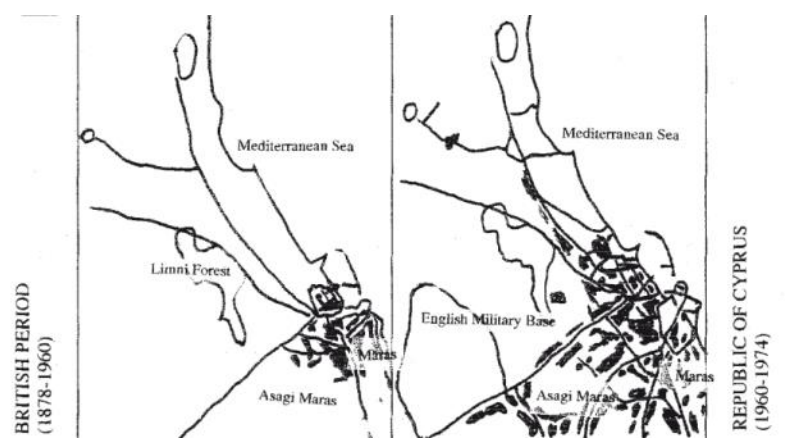

Figure 2. Urban explosion in Gazimagusa from 1960 till know (Onal et al., 1999).

2.2. Factors which have an influence on the identity of the city of Gazimagusa (Famagusta) Identity of cities is acquired with their original characters. "By passing the time, some cities lost their original architecture and urban characteristics, thus the settlement fall into a confusion of identity. In the case of Gazimagusa, economic structure, urban culture, reflection of climate factors to the physical structure and lifestyle of urban dwellers, construction techniques can easily readable"( Kutsal, 2012). As a result, physical environment, socioeconomic conditions, cultural and historical characteristics are the main factors in identity of the city of Gazimagusa.

\subsection{Analyzing the identity of the historical part of the city of Gazimagusa with its new developed parts}

\subsubsection{Physical Structure of the City}

In the walled city of Gazimagusa houses are usually one or two story buildings with the courtyards at the back. "Horizontal lines dominant on facades as in traditional Turkish houses, projections, Cikma or Cumba, give a unique character to the house as well as to the street long which they are located.

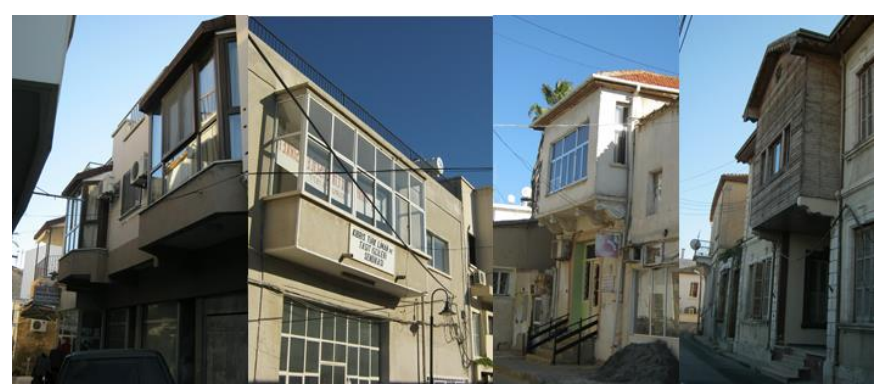

Figure 3. Cumba (facade protuberance) was a notable architectural expression of the Ottoman culture. (Walled

City, Famagusta .Photo by author. 9th Januar 2016).

Unfortunately in today's housing in gazimagusa in the outer part of walled city there is no evidence to show usage of Cumba in the building. Also this element of the city is from the past but it's part of traditional Turkish housing which has influence on identity and sustainability of historic urban cities. "In vernacular Cypriot houses, there are a rich variety of open and semiopen spaces, such as open-to-sky courtyards, verandas at the front and Sundurmas at the back, all with access to greenery. In a courtyard, Avlu in Turkish, and Havli in local Cypriot Turkish, 
compared to other kinds of open terrain, the sense of enclosure and small scale is easily manipulated, and given a mixture of hard and soft treatments"(Oktay, 2002).
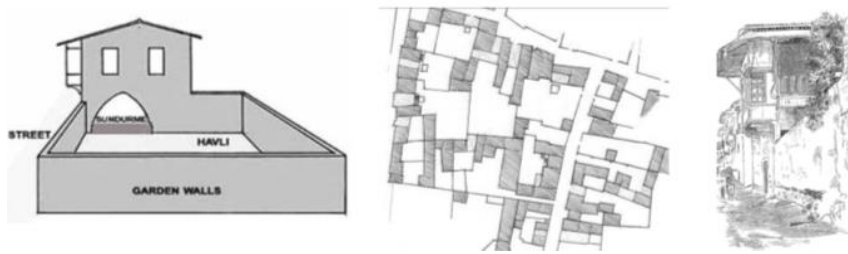

Figure 4. Havlı as the elementary spatial cell of the urban fabric (Retrieved from URL1. 30th December 2016).

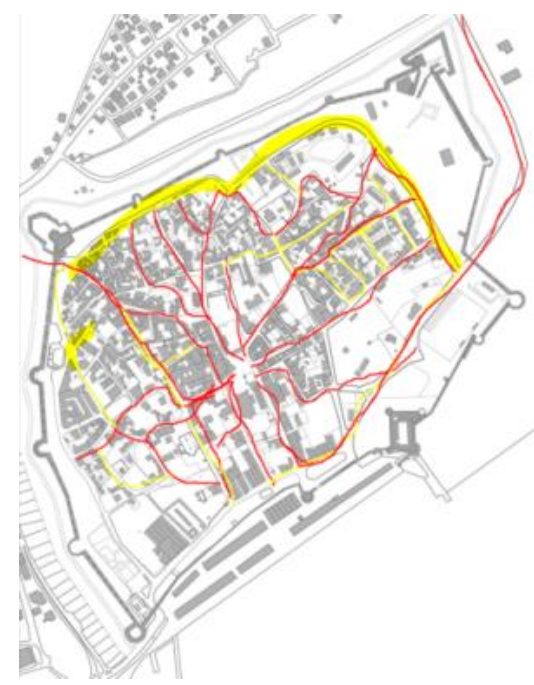

Figure 5. Organic pattern, together with the presence of some historic monumental structures and a definite center, greatly contribute the image ability and identity of the walled city of Famagusta.

\subsubsection{Streets and urban context}

Medieval cities in North Cyprus with its narrow streets which works in human scales. This compact form works properly with its context, streets are integrated into each other to helps the context of the city to be in a sustainable way. After modern construction in cities by entering cars in context, the meaning of cities has been changed. The street dos not mean much for attaching people to the urban environment. Straight streets with its cares are threatening the city's sustainability in North Cyprus. Due to dynamic of urban growth the city expanded itself to the exterior part of the city. Streets as vital glve, sticks all variables of context with each other. Unfortunately the modern form of the streets couldn't work properly for this reason the context of the cities are in danger of unsustainability.

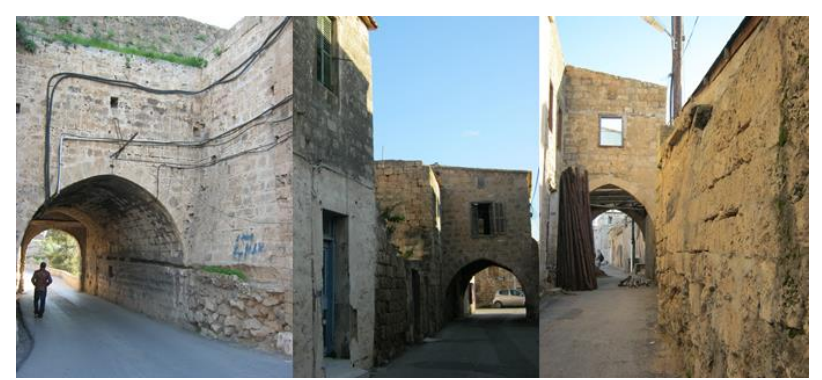

Figure 6. Street in the traditional quarter of Gazimagusa (Photo by author. 9th Januar 2016, Walled Ctiy).

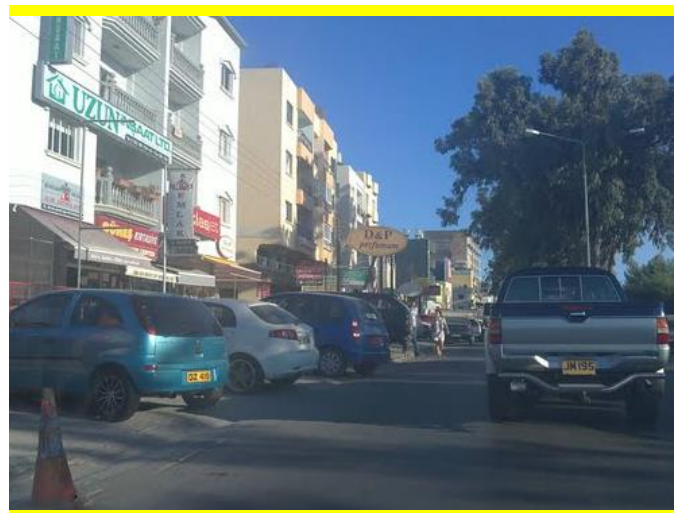

Figure 7. street in recently development part of Famagusta(Photo by author, 30th Decebmer2016).

\subsubsection{Square}

"The square is the most distinct element of the urban structure, determined by the same formal factors as the street, with the difference being that the buildings should form a continuous boundary around the space" (Oktay, 2006). Fortunately squares in historical part of the city of Gazimagusa in North Cyprus are steel maintain its own characteristic. Most successful squares in these parts of cities have mixed us functionality to attract a different type of people into it. Such this kind of Square is in the Walled city of Famagusta called Namic kemal plaza with its monumental church and different type of functionality. On the other hand the functionality of squares in new development part of the city could not attach itself with its surround. The square has been designed just for automobiles. 

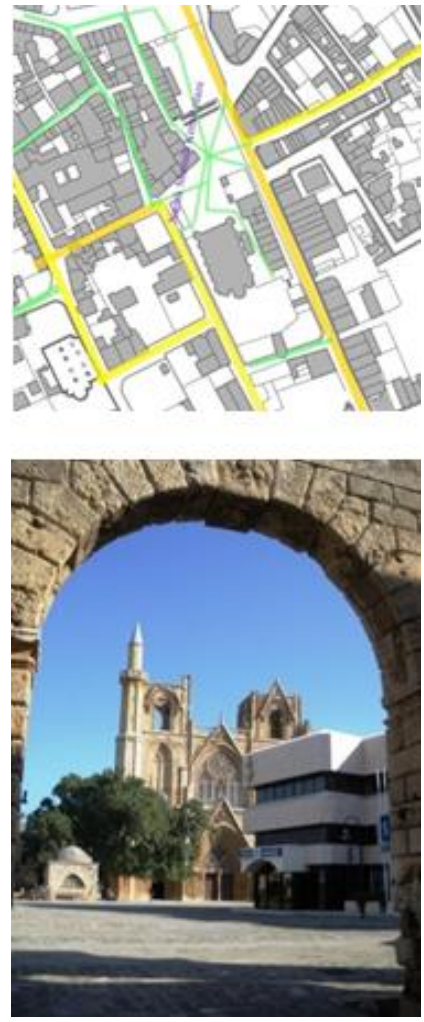

Figure 8. Namic Kemal plaza;by integrated all people and functions with each other has important characteristic on identity of the city of Famagusta. (Retrieved from URL3. 30th December 2016)

Unfortunately in this era the meaning of square has been changed. The squares are just for cars, there is no any activity or functionality to invite people into it. Thus here we can say that modern squares couldn't work properly with its environment

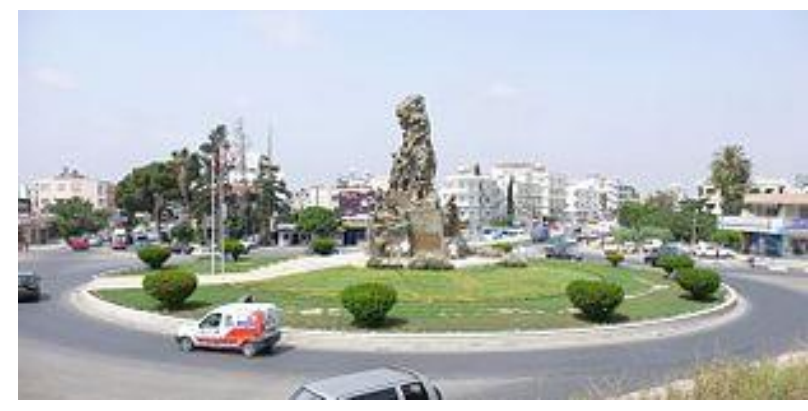

Figure 9. A view from the modern city center of Famagusta (Photo by author 20th December, 2016).

\subsubsection{Social-spatial patterns}

\subsubsection{The Context of Neighbourhood}

According to Jacobs (1961) in the context of the neighborhood, "urban space should be conceived as an outdoor room, somewhere to relax and enjoy from the urban experience". "When local urban context is considered, the district or quarter (neighborhood) is the identifying symbol both for the evaluation of city and for the new urban extension, it is also essential for sustainable development" (Oktay, 1998). To create a memorable place it seems that we need creative design in context of the neighborhood. Mahalle is an important unit in Turkish society, neighborhoods were not just a physical relation among each other; also works as a social and economic collaboration.

Unfortunately in new development part of Famagusta (e.g. Karakol neighborhood) the traditional meaning of Mahalle has been changed. This place doesn't have any place to 'relax and enjoy'. (It doesn't have mixes use functionality almost $90 \%$ of the building are for residential purposes). The place doesn't integrate properly with each other, there is no any place for social activity these factors are important which have influence in the identity of the city.

\subsubsection{Socio- Economic Structure of the city}

2.3.3.1. Problems in urban identity considering Financial benefits

"The economic structure of the city causes changes in the physical entity of spaces. Therefore changes in economic structure have an influence on the social structure and changes physical spaces. As a result these changing processes are effective in changing the urban identity" (Kutsal, 2012). To make rapid production; in global scale the modal housing construction started execution without consideration of local elements in the city so, that all cities have fallen into the danger of losing their identities in the process of similarization. Such this kind of similarization is everywhere in the city. By critical analysis of new development part of the city with Socio- Economic point of view, it seems that the main reason in today's mass construction came back to the idea of globalization to earn more money. Unfortunately 
in this proses of construction there is no any effort to highlight the historical identity of the city it seems that financial purpose are dominant for mass housing constructors.

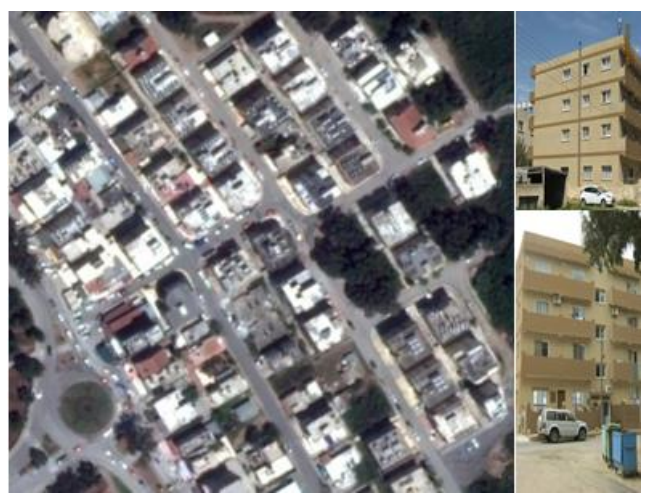

Figure 10. karakol neighborhood in North Cyprus. (Photo by author and site plan retrieved from URL3)

\subsubsection{Socio-Cultural Factors}

Multistory apartments in the outer part of the walled city of Famagusta are the yield of globalization. Previously, the houses had been constructed horizontally, and later on were designed vertically due to increasing in population. Therefore "the families had to live together, thus different type of culture occurred due to the residential development. Lifestyle, neighborliness, identity, and the terms of belonging were provided for sharing, participation and consensus were adopted. Generally, the lifestyle of the people who live in apartments changed, and this changing process provided for changing in the urban identity" (Kutsal, 2012). The apartments have, also, led to weakening the concept of social relations in the city. Today, one of the most important factors of losing the identity of the city is that the elimination of cultural icons; as a consequence people lost the sense of belongings to the environment.

However, when the rates of consumption were increased, today the "fashions" are changing rapidly. This changing accelerated the process of changing the urban identity. Living in an apartment became a new trend that comes from the west. In this process people left of their traditional houses and started to live in apartment buildings. Whereas the historical towns were left to ruin or to low income migrants to the cities. It's obvious from this part that SocioCultural factors in the new development of the city have been changed; globalization is the main factor in the changing of lifestyles of people with new trends and fashions.

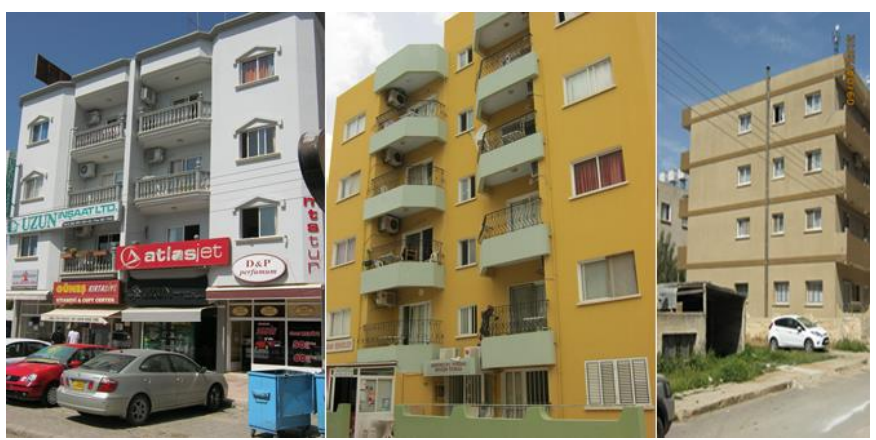

Figure 11. Financial benefits is the main aim in housing in global scale (photo by author, 20th December, 2016) .
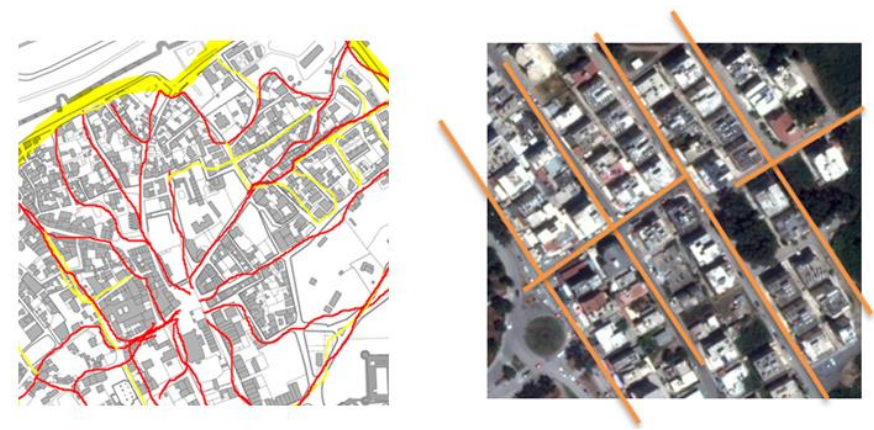

Figure 12. Strongly integration in historical part of Famagusta and week integration in new development part of it.

As figure 12 revealed lack of environmental integration with each other without using traditional housing principles in new development part of the city are the main factor in loosing feeling attachment with the environment and consequently these factors had an influence on loosing identity of the city. By critically analysis of new housing schemes in Gazimagusa (Famagusta) it's obvious to say that new housing environment in Gazimagusa follows the scheme of Globalization without respect to its historical context the result of this kind of urban expansion are; 
-Lack of Relationship between development and wider urban context

- There is no any cohesion whit its surround

- Quality of public space (e.g., Design, shape and scale) is in poor condition

For these reasons as Oktay (2002) mentions new housing construction could not achieve its goals to create a place with its own identity to attract people into it. Therefore the Identity of settlement and sense of Place in new development part have been disappeared. In figure 13 the author tried to compare the factors which have influence in the identity of the city of Gazimagusa. The method is to compare historical part of the city with new development part of Famagusta (figure 13) reveals factors which reducing identity of the city, is somehow related to the globalization to earn more money. For this reason they could not use historical Pattern which shows urban identity.

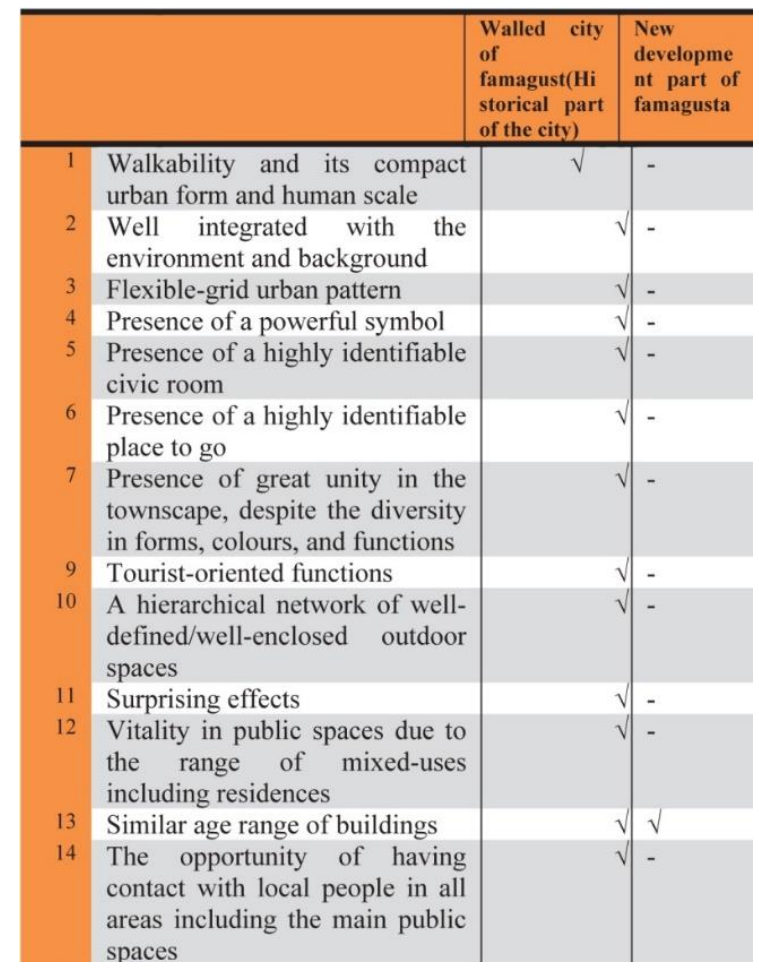

Figure 13. Urban context and sense of attachment to the environment in new and historical part in city of Gazimagusa (Famagusta).

Overall, theoretical evaluations in this study, following housing principles have been developed for urban designers and Architects to enhance the urban identity by enticing people into the context.

\begin{tabular}{|c|}
\hline -Landmark to increase the imageability \\
\hline $\begin{array}{l}\text {-each building needs to have its own identity. } \\
\text { At the same time, the building needs to have } \\
\text { harmony with the context. }\end{array}$ \\
\hline -Mixed used functions needs for downtown. \\
\hline -Walkability \\
\hline -Civic rooms to increase sense of belonging \\
\hline -Designing a pleasurable place \\
\hline $\begin{array}{l}\text {-Landscape of the city needs to be designed } \\
\text { and developed by specialist in this field. }\end{array}$ \\
\hline $\begin{array}{l}\text {-Permeability needs to be consider in } \\
\text { designing }\end{array}$ \\
\hline $\begin{array}{l}\text {-Specific events needs to be consider in } \\
\text { design public spaces }\end{array}$ \\
\hline $\begin{array}{l}\text { Universal approaches in urban design is also } \\
\text { needs to be consider }\end{array}$ \\
\hline
\end{tabular}

\section{Conclusion}

Walled city of Gazimagusa with its historic magnificent building, human scale narrow streets, Cul De Sacs and monumental buildings have its own identity which works on a global scale by its port and tourists. Unfortunately after 1960 because of globalization purposes, urban explosion by expanding it to the outer part of the city could not adapt with historical patterns. It means that the factors of Man-made Environme in city scale, district scale, and space scale have been changed. Urban fabric characteristic of the new development part of the city is different from the historical part of it. Related to this research question (Why urban sprawl could not maintain the identity of the city of Gazimagusa?) this survey revealed that globalization by neglecting historical housing principles is the main factor which threatening identity of the city.

In the era of transformation from traditional to globalization, redefinition characteristics of the walled city of Famagusta which have influence on the identity of the city (e.g., Avlu or Havli, Cumba etc.), and principles of vernacular housing, would be useful to redefinition of identity of the city. As a conclusion for housing in urban context related to city identity the best 
urban expansion is those designed with a sensitive understanding of their urban context, valuing the characteristics of the place including the character of the area and by respecting to its physical context, and the local pattern of physical objects, landscape, public space and topography.

The question of how it's possible to polarize mass housing constructors to use vernacular trends in new housing schemes? Proposed from author as future study.

\section{Acknowledgments}

This research did not receive any specific grant from funding agencies in the public, commercial, or non-for-profit sectors.

\section{References}

Brueckner, J.K. (2001). Urban sprawl: lessons from urban economics. In: Gale, W.G., Pack, J.R. (Eds.), Brookings-Wharton Papers on Urban Affairs 2001, Brookings Institution Press, Washington, DC.

Deng, F., \& Huang, Y. (2004). Uneven land reform and urban sprawl in China: the case of Beijing. Progress in Planning, 61 (3), 21 1-236. doi:10.1016/j.progress.2003.10.004

Ewing, R. (1997). Is Los Angeles-style sprawl desirable? Journal of American Planning Association 63, pp.107-126.

Eldemery,I.M. (Winter, 2009). Globalization challenges in architecture. Journal of Architectural and Planning Research. 26(4).pp. 343-355.

Fasli, M. (2010). A Model for Sustaining City Identity: Case Study: Lefko?a (Nicosia) in North Cyprus. VDM Verlag Dr. Müller.

Fischel, W.A. (2001). The Homevoter Hypothesis: How Home Values Influence Local Government Taxation, School Finance, and Land-Use Policies. Harvard University Press, Cambridge.

Gordon, P., Richardson, H. (1997). Are compact cities a desirable planning goal? Journal of American Planning Association 63(2), pp. 95149.
Jacobs, J. (1961). The Death and Life of Great American Cities. Random House: New York.

Kutsal, B. (April 2012) The Effects of the Changing of Urban Identity on Historic Towns. 1st International Conference on Architecture \& Urban Design. Retrived from: www.icaud.epoka.edu.al.pp.255-265.

Moughtin, C., (1996). Urban Design: Green Dimensions. Butterworth Architecture: Oxford.

Oktay, D., (1996). Notes on Urban Design. Gazimagusa; EMU Press. 52-63.

Oktay, D. (July 2001). Urban Identity in the Changing Context of the City: The Case of Gazimagusa (Famagusta). Paper presented at the Proceedings of LIVENARCH 2001 / Liveable Environments and Architecture International Congress, Trabzon, Turkey. Retrieved from ftp://ftparch.emu.edu.tr/Courses/Udes/Udes 501 (used on 20th December, 2016).26-35.

Oktay, D. (2002). The quest for urban identity in the changing context of the city: Northern Cyprus. Cities, 19(4), 261-271. Doi: 10.1016/S0264-2751 (02)00023-9.

Oktay, D. (2006). "How can urban context maintain urban identity and sustainability? Evaluations of Taormina (Sicily) and Kyrenia (North Cyprus)", WEB JOURNAL ON CULTURAL PATRIMONY, Vol. 1, No. 2.

Önal, Ş., Dağli, U., \& Doratli, N. (1999). The urban problems of Gazimagusa (Famagusta) and proposals for the future. Cities, 16(5), 333-351. Doi: 10.1016/S0264-2751 (99)00031-1

Smith, D. A. (2001). Globalization and Social Problems. Social Problems, 48(4), pp.429-434. doi:10.1525/sp.2001.48.4.429

The definition of globalization. (n.d.). Dictionary.com. (Retrieved on December 30, 2012), from http://dictionary.reference.com/browse/glo balization

URL1, Municipality maps of walled city. (2016). Walled city. Walled city, Famagusta, Cyprus. Retrieved from;http://famagustawalledcity.org/01- 
Venetian-Fortifications-Land-Gate-and-

Ravelin (used on 20th October, 2016).

URL2, Famagusta municipality. (2016).

Population of Famagusta in 2006 retrieved from:

http://www.magusa.org/English/population. htm. On 11 January 2016.

URL3, Google maps. (2016). Walled city and its lost spaces. Walled city, Famagusta, Cyprus.

Retrieved

from:

https://maps.google.com/maps?hl=en\& $\mathrm{q}=\mathrm{f}$ amagusta+gazimagusa+map\&ie=UTF-

$8 \& h q=\& h n e a r=0 \times 14 d f c 842 d a 4 c 163 d: 0 \times 29 d b$

03c5a5d3ce87,Ammochostos\&ei=heCQUK6 wCITNswbQmoHYCQ\&ved=0CDCQ8gEwAA.

(Used on 20th October, 2016 
www.ijcua.com

This page is intentionally left blank. 